Georgetown University Law Center

Scholarship @ GEORGETOWN LAW

2001

\title{
Ethics in ADR: The Many "Cs" of Professional Responsibility and Dispute Resolution
}

Carrie Menkel-Meadow

Georgetown University Law Center, meadow@law.georgetown.edu

This paper can be downloaded free of charge from:

https://scholarship.law.georgetown.edu/facpub/524

http://ssrn.com/abstract=288805

28 Fordham Urb. L.J. 979-990 (2001)

This open-access article is brought to you by the Georgetown Law Library. Posted with permission of the author. Follow this and additional works at: https://scholarship.law.georgetown.edu/facpub

Part of the Dispute Resolution and Arbitration Commons, and the Legal Ethics and Professional Responsibility Commons 


\title{
ETHICS IN ADR: THE MANY "Cs" OF PROFESSIONAL RESPONSIBILITY AND DISPUTE RESOLUTION
}

\author{
Carrie Menkel-Meadow*
}

I have been teaching both alternative dispute resolution ("ADR") and professional responsibility for a long time, and I will devote the majority of this essay to reporting on some of the enormous changes and developments in this field. However, I will begin with a mea culpa at a higher level of ethical consciousness than the rules that govern us, or are about to govern us, typically use. I have spent the last five years of my life writing ethical rules for ADR, and I am worried about the future of this field. There are many changes occurring in ADR, and I now fear that, because of all the activity, we are about to encounter the possibility of "conflicts of laws" with respect to ethics in the practice of alternative dispute resolution. If we do not already, we soon will have many different rule systems governing our practice, some of which explicitly conflict with each other and others of which are implicitly or indirectly in conflict.

This field, which I prefer to call "appropriate" dispute resolution, ${ }^{1}$ was intended to be flexible, make the world a better place, and encourage different models of problem solving-not only adversarial ones, but conciliatory ones. Yet appropriate dispute resolution is now becoming as complex, law-laden, and law-ridden as the traditional practice of law.

From the outset, I have been a strong proponent of the need for rules, regulations, and best practices standards because I care that ADR is practiced "appropriately." We now call it "appropriate dispute resolution," rather than "alternative dispute resolution," precisely to signal that different processes may be appropriate for

* Professor of Law, Georgetown University Law Center; Visiting Professor, Harvard Law School; Chair, Center for Public Resources Institute for Dispute Resolution-Georgetown University Commission on Ethics and Standards of Practice in ADR. Thanks to Meredith Weinberg for her research assistance. This essay is based on transcribed remarks delivered at the Association of American Law Schools' Annual Meeting, Joint Session of the Sections on Professional Responsibility and Alternative Dispute Resolution.

1. See Albie M. Davis \& Howard Gadlin, Mediators Gain Trust the Old-Fashioned Way-We Earn It!, 4 NEG. J. 55, 62 (1988) (introducing the phrase "appropriate dispute resolution"). 
different kinds of disputes or in different types of settings. By using that label, we also acknowledge that we must make choices about how to conduct different processes appropriately. We are looking for the most appropriate way to try to resolve disputes, plan transactions, solve international crises, and deal with community and individual human problems. Therefore, ADR really is intended to encompass more than just alternatives to a litigation system.

This broadening of ADR presents the most troubling of the issues in the development of the field in ethics, which is one of jurisdiction. Who has, or ought to have, ethical control over the practice of this multi-disciplinary field, that draws from the teachings and standards of many different professional and non-professional structures and ideologies? There, too, mea culpa. I have been published widely as someone who is concerned about the unauthorized practice of law. ${ }^{2}$ I do believe that some forms of evaluative mediation and, these days, hybrid forms of arbitration, multiparty dispute resolution, consensus building-many of the new practices-ultimately prompt third-party neutrals to opine on the law, suggest legal conclusions, or advise people in ways that, although they do not create a technical lawyer-client relationship, do implicate the giving of legal advice and may cause some people to rely inappropriately on the statements of third-party neutrals. Thus, I am concerned about liability issues and whether some dispute resolution practitioners' activities constitute the unauthorized practice of law. ${ }^{3}$ I will not focus on that issue in this essay, other than to recognize it as one of the issues posed by the question of determining who ought to regulate this multi-disciplinary practice. Moreover, for those lawyers who want to encourage non-lawyers

2. E.g., Carrie Menkel-Meadow, Is Mediation The Practice of Law?, AlternaTIVES, May 1996, at 57. Whenever I make arguments about the unauthorized practice of law, I think of my good friend, co-mediator, and co-trainer, Howard Gadlin, who is a psychologist by training. E.g., The Conflict Resolution Information SOURCE, The Guide to Dispute Resolution Practitioners and Researchers (containing Dr. Gadlin's biographical information), http://crinfo.org/documents/h-bio/Gadlin_H.htm. When I complain about non-lawyers opining on the law, Dr. Gadlin suggests that perhaps lawyers should be charged with the unauthorized practice of psychology, since they attempt to facilitate parties' communication with little or no training and, often, little or no skill. For an effort to provide some communication skills generically, see Douglas Stone et al., Difficult Conversations: How to Discuss What Matters Most (1999).

3. E.g., Office of the Executive Sec'y, Supreme Court of VA., Guidelines on Mediation and the Unauthorized Practice of Law (1999) [hereinafter ViRGinia Guidelines], http://www.courts.state.va.us/drs/upl/preface.html. 
to contribute their additional learning and teaching, how should we combine these multiple disciplines? ${ }^{4}$

Turning to the major ethical concerns in the practice of ADR, we may simplify the discussion a bit by considering what I call the "Four Cs of Ethics and ADR." The first " $C$," which is largely absent from the rules, is the issue of counseling about ADR. Every lawyer ought to have an ethical obligation to counsel clients about the multiple ways of resolving problems and planning transactions. A few states have included this obligation in precatory language, ${ }^{5}$ although very few have done so in required language. ${ }^{6}$ I think that this ethical obligation should be mandatory, and I have suggested this in my idealized Ten Commandments of Appropriate Dispute Resolution. $^{7}$

The second "C" of ethics and ADR is confidentiality. Although our current ethics rules do not address confidentiality in detail, ${ }^{8}$ there is much regulation of confidentiality issues at the state level, ${ }^{9}$ and there soon will be regulation at the federal level, as well. ${ }^{10}$ Indeed, Attorney General Janet Reno appointed a federal agency to coordinate federal ADR, ${ }^{11}$ and the Code of Federal Regulations and Federal Register soon will contain proposed regulations for confidentiality in federal ADR. ${ }^{12}$ These new regulations raise a

4. Several organizations have attempted to draft ethical rules to transcend disciplinary boundaries. E.g., Am. Arbitration Ass'N et Al., Model Standards of CONDUCt FOR Mediators (1994), http://www.adr.org/rules/ethics/standard.html.

5. See Marshall J. Breger, Should An Attorney Be Required to Advise a Client of ADR Options?, 13 Geo. J. Legal EThics 427 (2000).

6. Id. at 462 app.I.

7. Carrie Menkel-Meadow, Ethics and Professionalism in Non-Adversarial Lawyering, 27 FLA. ST. U. L. REv. 153, 167-68 (1999).

8. The current version of the Model Rules of Professional Conduct does not treat any of the substantial ethical issues with respect to lawyers serving as third-party neutrals. The traditional protection of confidentiality of lawyers and clients, Rule 1.6, applies only to those in the privity of lawyer-client relationships. MODEL RULES OF Prof'L Conduct R. 1.6 (1999). Typically, parties and third-party neutrals are not in this lawyer-client relationship. Rule 2.2 , which attempts to deal with the lawyer serving as "intermediary" between two clients, simply assumes that the clients have no confidentiality as between them if they are both using the same attorney. Model Rules of Prof'l Conduct R. 2.2 (1999).

9. See e.g., Nancy Rogers \& Craig McEwen, Mediation: Law, Practice AND Policy (2d ed. 1994).

10. Notice, Confidentiality in Federal Alternative Dispute Resolution Programs, 65 Fed. Reg. 83,085 (Dec. 29, 2000).

11. Fed. Alternative Dispute Resolution Council, Report on the ReaSOnable Expectations of Confidentiality Under the Administrative DisPUTE RESOLuTION ACT OF 1996 (2000), http://www.financenet.gov/financenet/fed/ iadrwg/confid.pdf.

12. Notice, 65 Fed. Reg. at 83,085 . 
whole host of issues for those of us who are interested in the law of privilege, evidence, and the Freedom of Information Act. At both the federal and state levels, the ethical issues about confidentiality in ADR conflict with "sunshine laws" and other open government policies, ${ }^{13}$ and demonstrate the competing values that inform ADR. Again, the question remains: Who should resolve those issues?

The debate over Rule $4.2^{14}$ presents another interesting issue with relevance to whether state ethics rules govern federal lawyers and law enforcement officials. If the federal government has a regulatory scheme for confidentiality or other issues, what do state ethics rules, state evidence rules, or state mediation privileges have to do with ADR practice at the federal judicial or regulatory level? These conflicts of laws/conflicts of rules issues are quite complex. The Honorable Wayne Brazil, a former law professor and current magistrate judge who developed one of the most advanced ADR programs in the federal courts, is a notable founder in our field who has had to deal with these issues. ${ }^{15}$ In a recent case, Judge Brazil addressed some of these questions about which level of regulation governs confidentiality of mediation in the federal courts. ${ }^{16}$

This leads me into the third " $C$," conflicts of interest, as well as into conflicts of rules and laws. We have multiple levels of regulation in ethics and ADR for conflicts of interest for third-party neutrals, lawyers who participate as party representatives and advocates, and former, present, and potentially future parties and clients in ADR proceedings.

There are substantive laws, ethics rules, and court rules about ADR and conflicts of interests at both the federal and state level.

13. See Charles Pou Jr., Ghandi Meets Elliot Ness: 5th Circuit Ruling Raises Concerns About Confidentiality in Federal Agency ADR, Disp. Resol. Mag., Winter 1998, at 9 (discussing the balance between openness for oversight and confidentiality for potentially volatile issues); Christopher Honeyman, Confidential, More or Less: The Reality, and Importance, of Confidentiality is Often Oversold by Mediators and the Profession, Disp. Resol. MAG., Winter 1998, at 12 (arguing that claims of "confidentiality" can be exaggerated unnecessarily).

14. Rule 4.2 provides that "a lawyer shall not communicate about the subject of the representation with a person the lawyer knows to be represented by another lawyer in the matter," unless the lawyer is authorized by law or given consent by the other lawyer. Model Rules of Prof'l Conduct R. 4.2 (1999).

15. E.g., Wayne D. Brazil, Settling Civil Suits: Litigators' Views About Appropriate Roles and EfFective Technioues for Federal Judges (1985); Wayne D. Brazil, Effective Approaches to Setrlement: A Handbook for LAWYERS AND JUDGES (1988).

16. Olam v. Cong. Mortgage Co., 68 F. Supp. 2d 1110 (N.D. Cal. 1999) (noting the tension between federal court rules that mandate confidentiality and state law). 
At the state level, California, Florida, Massachusetts, Minnesota, New York, and Texas have been most active in addressing potential conflicts. ${ }^{17}$ These particular states are notable because they have regulated conflicts of interest and confidentiality in substantive statutes providing for ADR or mediation in evidentiary rules,${ }^{18}$ as well as in procedural court rules. ${ }^{19}$ So there are both substantive regulations, procedural rules, and court rules that exist at multiple jurisdictional levels. Determining whether an arbitrator or mediator has a prohibited conflict of interest (involving a former, present, or potential future client) may require consultation with a wide variety of rule systems, including formal law and the many rules created by private associations of mediators and arbitrators. ${ }^{20}$

Because I have written elsewhere about the complexity of conflicts of interest issues in ADR, ${ }^{21} \mathrm{I}$ will mention just some of the key controversies. The major issue, both at the policy and rule levels, is the extent to which the same individual should be allowed to perform multiple roles as mediator and as advocate, at different times and in different cases, in order to encourage the expanded use of ADR. There is also a question of whether mediators, conciliators, arbitrators, and other dispute resolvers should be allowed to practice in law firms with others who perform the more conventional advocate's role, sometimes for the same or adverse parties.

Under our current ethics rules for lawyers, ${ }^{22}$ this situation is very problematic. Should a mediator preside over a matter in which that mediator, or his or her partner, may later represent one of those parties in either a related, substantially related, or unrelated matter? Should there be a time frame limiting that representation,

17. ROGERs \& McEWEN, supra note 9, at app.A (summarizing provisions of state confidentiality statutes).

18. E.g., CAl. Evid. Code $§ 2025$ (West 2000); see also Rogers \& McEwen, supra note 9, at app.A (detailing the evidentiary issues that arise in mediations in areas such as discovery, evidence, public access, non-parties, and protective orders).

19. E.g., ADR L.R. 2-5(d) (N.D. Cal. 2000) (establishing procedure for determining conflicts of interest in ADR context).

20. E.g., Am. Arbitration Ass'n, Code of Ethics for Arbitrators in ComMERCIAL DisPUTES (1977), http://www.adr.org/roster/arbitrators/code.html.

21. E.g., Carrie Menkel-Meadow, Ethics in Alternative Dispute Resolution: New Issues, No Answers From the Adversary Conception of Lawyers' Responsibilities, $38 \mathrm{~S}$. Tex. L. Rev. 407 (1997) [hereinafter Menkel-Meadow, New Issues, No Answers]; Carrie Menkel-Meadow, The Silences of the Restatement of the Law Governing Lawyers: Lawyering as Only Adversary Practice, 10 Geo. J. Legal Ethics 631 (1997).

22. Model Rules of Prof'L Conduct R. 1.7 (1999) (describing prohibitions and exceptions for conflicts of interest in representation); id. R. 1.12 (explaining rules of representation for former judges and arbitrators). 
or should it be allowed to occur with client or party consent, or not at all?

If you have not been following the debate, this is where I sometimes fear I have wasted the last five years of my life arguing with the ABA Ethics 2000 Commission on the Evaluation of the Rules of Professional Conduct (the "Commission" or "Ethics 2000 Commission"). ${ }^{23}$ In my view, many ethicists, professional responsibility scholars, rule drafters, and practicing lawyers still do not get itthat is, they do not understand what ADR is all about. They do not recognize how the conceptions, purposes, and information flows of ADR practice differ from those of more conventional legal practice. At the same time, there is a risk that conventional advocates will use ADR to "game" the system, leaking information and manipulating the processes in ways that do need to be regulated.

The current report of the Ethics 2000 Commission, which will be presented to the ABA House of Delegates, has at least three ADR-related provisions. First, the new Preamble to the Rules recognizes that lawyers may serve as third-party neutrals and may exercise peacemaking, as well as advocacy, functions. ${ }^{24}$ This is a useful, if mostly symbolic, step forward.

Second, the newly proposed Rule 2.4 formally recognizes the role of the third-party neutral within the context of services performed by lawyers. ${ }^{25}$ The Rule only states that third-party neutrals may be used, and that lawyers behaving as third-party neutrals should describe their function and explain that they are not representatives of the parties. The Rule suggests that lawyers serving as third-party neutrals should advise unrepresented parties to consult with lawyers if they either want legal advice or wish to understand the details and complexities of ADR processes. There were additional proposals about what might have been included in the rule, such as whether mediators and other third-party neutrals could

23. The Ethics 2000 Commission has completed its report of proposed changes to the Model Rules of Professional Conduct, which will go to the ABA House of Delegates this summer. ABA Ethics 2000 Comm'N on the Evaluation of the Rules of Prof'l Conduct, Final Rules Part Two (Nov. 2000), http://www.abanet.org/ cpr/e2k-final_rules2.html (providing the proposed rule changes and full Commission report).

24. Id., Preamble [3].

25. ABA Ethics 2000 Comm'n on the Evaluation of the Rules of Prof'L Conduct, Proposed Rule 2.4 (Nov. 2000), http://www.abanet.org/cpr/e2krule24.html. 
give legal information or advice, ${ }^{26}$ as well as whether mediators could serve as scriveners for agreements, drafting mediated agreements for the parties without running afoul of conflicts of interests or other rules. ${ }^{27}$ Nevertheless, in the interest of simplicity, these suggestions were not incorporated into the final proposed rules.

The third issue treated by the proposed new rules is a departure from current standards or silences on the issue of conflicts of interest. The newly proposed Rule 1.12 treats mediators as arbitrators and judges have been treated by the rules in the past. The rule permits screening, which allows an attorney who serves as a mediator in a law firm to be screened so that his or her partners may subsequently represent one of the parties in the mediator's matter without obtaining client consent. ${ }^{28}$

I still think that the Commission does not understand some of the subtleties and complicated issues involved in determining whether matters are substantially related, unrelated, or even the same for purposes of determining conflicts of interest. In a sense, this new screening rule actually permits a troubling "gray area" in which a conflict still may exist, such as when a screened mediator's partner serves as an advocate in an adversarial proceeding after an unsuccessful mediation in that same matter. The Commission simply chose to draw some bright-perhaps too bright-lines and treat mediators and arbitrators in the same way, where perhaps there are some real differences.

26. The Model Standards of Conduct for Mediators state that mediators never should give legal advice. E.g., Am. Arbitration Ass'N et al., supra note 4, Rule VI, $\mathrm{cmt} .4$. The Virginia standards state that mediators can give legal information, but not legal advice. Virginia Guidelines, supra note 3. The distinction between these two has always eluded me, see, e.g., Menkel-Meadow, New Issues, No Answers, supra note 21 , at 454 .

27. The Judicial Council of Virginia has adopted ethical standards stating that, although mediators are not prohibited from drafting agreements between parties, they are obligated to encourage review by independent counsel prior to either party signing the agreement. Judicial Council of Va., Standards of Ethics and ProFessional Responsibility fOR Certified Mediators (Oct. 2000), http:// www.courts.state.va.us/soe/soe.htm.

28. ABA Ethics 2000 Comm'n on the Evaluation of the Rules of Prof'L Conduct, Proposed Rule 1.12 (Nov. 2000), http://www.abanet.org/cpr/e2krule112.html. The proposed rule contains some ambiguity. It is "clear" ethical practice that mediators almost never serve as advocates in an actual, or substantially related, case that they have mediated. Current ethical disputes are about cases involving the same clients or parties in slightly or very different matters. From these principles, it would seem that a mediator's partners also should not be allowed to serve as representatives in the same or a substantially similar matter (in other words, the old imputation rule should apply here), but this result is not clear from the current version of the rule. 
The rule also singles out "partisan arbitrators" as being similar to advocates, even though partisan arbitrators are an entirely separate group currently receiving a great deal of practitioner, if not scholarly, attention. Ethically, is the partisan arbitrator to be "just another lawyer" on the case, subject to the ethics rules for advocates, or is the partisan arbitrator to be more neutral? ${ }^{29}$

I want to explain why this screening rule is so significant. I personally did a 180-degree turn on this issue. As a strict ethicist and someone who deplored conflicts of interest in conventional adversary practice, I began my work in this field thinking that screens for mediators and arbitrators should not be permitted. I have since changed my mind completely, for policy reasons. Specifically, that policy should encourage both traditional adversary practice and the fourth "C," conciliation, within a single law firm.

The practice of law will be better informed if people are permitted to be mediators, arbitrators, and advocates within the same practice units, which in turn will provide greater information resources for clients and lawyers. My utopian hope is that the culture of law practice might change if third-party neutrals, conciliators, and advocates inhabit the same offices. Thus, I have spent a fair amount of the last few years trying to get the screen provision put in place.

I am concerned that there still are complicated issues not covered by the current draft of the rule. As an illustration, a few months ago I was training some extremely sophisticated intellectual property lawyers in mediation, and I talked to them about these ethics issues. Professional responsibility teachers will be shocked to learn that when I described the proposed screen of the new Rule 1.12 as a positive phenomenon, these practicing intellectual property lawyers, who serve as both advocates and mediators, understood this new rule as prohibiting them from engaging in their current multiple kinds of practice, where they previously had not been cognizant of the potential conflicts of interests issues. In other words, they had not even conceptualized the possibility that when a lawyer serves as a mediator in one matter, his or her partner cannot represent one of the parties in that mediation in a related, or even an unrelated, litigation matter.

29. See Lawrence J. Fox, The Last Thing Dispute Resolution Needs is Two Sets of Lawyers for Each Party, in CPR Inst. For Dispute Resolution, INTO THE 21st Century: Thought Pieces on Lawyering, Problem Solving and ADR 47, 47 48 (2001). 
It was quite clear to me that these senior distinguished intellectual property lawyers, who were members of the pre-Watergate generation that had not taken professional responsibility courses, did not even recognize a conflicts of interest issue when they were in the midst of one. It was surprising, given all the bar associations' continuing legal education requirements, how little these lawyers knew about conflicts of interest. Most of these quite prominent lawyers have been mediating and representing parties without using screens and thinking the entire time that this was perfectly permissible. When I said, "The good news is that now you are going to be able to perform both of these roles, provided you screen in appropriate cases," they looked at me in horror, realizing that they would now need to engage in all the complexities involved in screening, such as the segregation of files and fees and the prohibition on discussions with firm partners on screened matters.

I offer that example to demonstrate: (a) the lack of knowledge that still exists about our very basic rules of conflict of interest, and (b) the significant effort that will be required to apply the complex conflict of interest rules and screening to the ADR environment.

Finally, I will review a number of other very interesting developments in the regulation of ethical issues in ADR. For the last five years, I have had the honor to chair the Commission on Ethics and Standards of Practice in ADR ("CPR-Georgetown Commission"), ${ }^{30}$ which develops some best practices in the field. This is where my heart really is, in trying to make the field responsible for acting appropriately and with good practices, while acknowledging that, perhaps, we are still too new and young to fully regulate what ought to happen. At the same time, we have been concerned with the quality of the field, and, in particular, with the role of lawyers who practice ADR in its myriad forms.

The CPR-Georgetown Commission has published two different documents, ${ }^{31}$ which I think are quite useful for teaching profes-

30. The Center for Public Resources Institute for Dispute Resolution-Georgetown University Commission on Ethics and Standards of Practice in ADR [hereinafter CPR-Georgetown Commission] is co-sponsored by the Center for Public Resources in New York and Georgetown University and funded by the William and Flora Hewlett Foundation.

31. CPR-Georgetown Comm'n, Proposed Model Rule for The Lawyer as Third Party Neutral (1999) [hereinafter CPR-Georgetown Comm'n, Proposed Model Rule], http://www.cpradr.org; CPR-Georgetown Comm'N, Draft PrinciPLes for ADR Provider Organizations (2000) [hereinafter CPR-Georgetown Comm'n, Draft Principles], http://www.cpradr.org. 
sional responsibility to students and training practicing mediators, arbitrators, and other third-party neutrals.

The first document, which has been out for about a year and a half, discusses our proposed ethics rules for lawyers who act as third-party neutrals. This document concludes that mediators may be lawyers and, therefore, they should be subject to all the ethics rules governing lawyers who practice law or any other profession. ${ }^{32}$ In a sense, this proposed rule, though far-reaching and complex, evades the question of what happens when mediators are not lawyers. It fails to address the potential competition that we lawyermediators may have with those who mediate from another discipline, and who may not be subject to our conflict of interest rules, fee rules, and other ethics rules.

The second document, Draft Principles for ADR Provider Organizations ${ }^{33}$ is somewhat inspired by the wonderful work of legal ethicist Ted Schneyer. ${ }^{34}$ This document is interesting because no other body has attempted a similar project. Essentially, Draft Principles for ADR Provider Organizations is an attempt to recognize one of the major changes in the legal profession, that is, that since organizations are providing legal services, there are situations in which these organizations should be responsible, both in liability and in ethics discipline, for the actions of their member service providers. The document also specifies some best practices for organizations that hold themselves out as either providers of ADR assistance, referrals, or direct services. These organizations would include such entities as courts, which maintain rosters of mediators and arbitrators; solo practitioners, like me, who hold themselves out as mediators, arbitrators, and consensus builders; and other third-party neutrals.

Draft Principles for ADR Provider Organizations has not been adopted by any regulatory entity, jurisdiction, state, or professional association, and so has no force of law. However, it does try to elucidate a series of best and responsible practices involving such issues as a graduated scale of information to be provided to parties in ADR. ${ }^{35}$ For example, if parties in the dispute have greater involvement in choosing their provider of ADR services, because

32. CPR-Georgetown Comm'N, Proposed Model Rule, supra note 31.

33. CPR-Georgetown Comm'N, Draft Principles, supra note 31.

34. E.g., Ted Schneyer, Professional Discipline for Law Firms, 77 Connell L. REv. 1 (1991) (discussing the law firm's role in regulating ethical behavior of lawyers and suggesting that discipline should be meted out at the firm level in appropriate cases).

35. CPR-Georgetown Comm'N, Draft Principles, supra note 31. 
they reviewed résumés or interviewed candidates for mediators and arbitrators, then the referral organization would have a concomitant lesser responsibility for the assigned ADR provider. If an organization, like a court, assigns an ADR provider without party choice or input, then that referral organization should assume greater responsibility for ensuring competence, proper credentials, and training, as well as for assuring that the assigned person provides ethically permissible services.

This is fairly controversial material. For example, those who work in the dispute resolution field know the American Arbitration Association often handles complaints about conflicts of interest, including the circumstances under which an arbitrator should reveal financial interest, past cases, or other conflicts that may affect the arbitrator's ability to remain neutral. An organization referring providers of dispute resolution services has an uncertain responsibility in assigning a third-party neutral to a case, as this activity is currently unregulated. However, several organizations that maintain panels and lists of mediators, arbitrators, and other third-party neutrals have promulgated their own internal ethical regulations, though they vary widely. ${ }^{36}$

Draft Principles for ADR Provider Organizations also is concerned about quality control, particularly in information and competence. When an organization suggests an ADR process or recommends a particular provider, it has an obligation, in the CPRGeorgetown Commission's view, to provide a lot of information about what it all means-both information about the process itself, the choice of neutral, and the type and quality of the neutral.

I would say, in a sense, there is a fifth " $\mathrm{C}$ " in the Ethics of ADR, and that is choice. One of the values underlying Draft Principles for ADR Provider Organizations recognizes the fact that parties increasingly have less choice about whether to go to ADR and which provider to use. Therefore, the entity recommending ADR-or, to use another " $C$," coercing it, such as in the mandatory referrals of some courts-should have some responsibility for assuring the competence and integrity of the process.

The CPR-Georgetown Commission's Draft Principles for ADR Provider Organizations might be a useful document to teach and study. In particular, it might be interesting for professional responsibility students to take a look at the larger question of entity or organizational ethical responsibilities at the more general level and

36. E.g., JAMS-EndisPute, Ethics Guidelines for ARBitrators, http:// www.jamsadr.com/ethics_for_arbs.asp; AM. ARBITRATION Ass'N ET AL., supra note 4. 
then to examine the specifics to see whether they would make different choices in these areas than the CPR-Georgetown Commission has made.

Draft Principles for ADR Provider Organizations also contains a very interesting taxonomy of all the different forms of ADR and all the different kinds of provider organizations, including courts, public entities, administrative agencies, private individuals, lawyers, and non-lawyers. It is a very nice way to educate people who do not know much about the field.

For people who are primarily professional responsibility teachers, rather than ADR teachers, scholars, or practitioners, if you do not learn this material, you are doing so at your own peril. This is one of the many ways in which the legal profession and legal practice is changing dramatically. Virtually every state and federal court requires some form of ADR at least to be considered by the lawyers in a litigation matter, ${ }^{37}$ and, increasingly, transactions and contracts contain ADR clauses. So if you teach professional responsibility, I urge you to get up to speed on the content of ADR - its aspirations, visions, and hopes-and also to realize that if you are looking for some interesting, complex, and new issues to teach your students, you will not find a more fertile field for both your mind and heart than that of thinking about the possible technical violations in ethics and what constitutes good practice in ADR.

37. E.g., Am. Arbitration Ass'n, State Statutes, http://www.adr.org (providing ADR statutes in all fifty states and the District of Columbia); 28 U.S.C. § 651(b) (2000) (requiring all district courts to devise and implement ADR programs). 